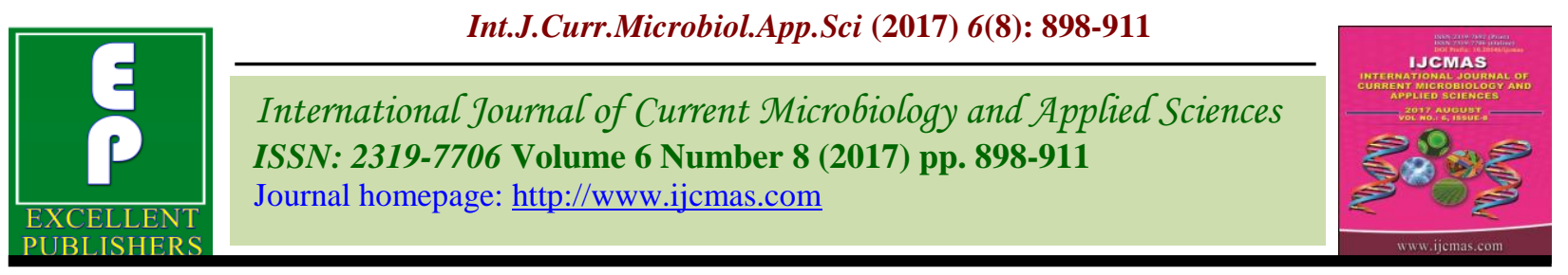

Original Research Article

https://doi.org/10.20546/ijcmas.2017.608.112

\title{
Nutritive Value and Fodder Potential of Different Sorghum (Sorghum bicolor L. Moench) Cultivars
}

\author{
Balasamy Jayaraman Karthikeyan $^{1} *$, Chakrapani Babu ${ }^{2}$ and John Joel Amalraj ${ }^{1,3}$ \\ ${ }^{1}$ Department of Plant Genetic Resources, ${ }^{2}$ Department of Forage Crops, \\ ${ }^{3}$ Centre for Plant Breeding and Genetics, Tamil Nadu Agricultural University, \\ Coimbatore - 641 003, Tamil Nadu, India \\ *Corresponding author
}

\section{A B S T R A C T}

Keywords

Sorghum, Forage yield, Fodder quality, Genetic diversity, Correlation, Forage standards.

\section{Article Info}

Accepted:

14 June 2017 Available Online: 10 August 2017
The current work was focused on evaluating 24 sorghum accessions for fodder yield potential and nutritional quality during summer 2015 in the Department of Forage Crops, TNAU, Coimbatore. Plant samples were collected at 50\% flowering stage and evaluated for nine fodder yield and 13 forage quality parameters. Grounded samples were used for assessing the fodder quality. The variety K 3 showed superiority for green fodder yield per plant with $1452.40 \mathrm{~g}$ followed by TKSV $1050(1409.47 \mathrm{~g})$ and the accession TKSV 1126 was exceptionally better in quality with high nutrition and less in fibre portions. Variability analysis observed that phenotypic selection of traits viz., number of leaves per plant, ether extract, dry fodder and green fodder yield per plant would be effective for fodder improvement. Genetic diversity analysis leads to the formation of five clusters. Cluster V had accessions with high yield potential and quality and Cluster II was confined with accessions having better forage quality. Furthermore, the accession TKSV 1126 obtained 'A1' grade (AFIA standards) with high nutritional quality; less fibre; better digestibility and metabolisable energy and could well be used as a donor in improving the nutritional content of sorghum varieties, which is lacking in the present-day cultivars.

\section{Introduction}

A large segment of the rural population comprising approximately 40 million people have 2-3 cattle and 5-6 sheep per family providing $30-40 \%$ of income for livelihood.

As the projected demand for fodder in India in 2020 is expected to be 855 MT of green fodder, 526 MT of dry fodder and 56 MT of concentrate feed (Dikshit and Birthal, 2010), as against the present demand of $666 \mathrm{MT}$ of green fodder and 138 MT of dry crop residues, there is a need to emphasize for increased fodder production so that we could provide more support to livestock industry in the country.

Sorghum (Sorghum bicolor L. Moench), the fifth most important cereal crop, is a gifted genus of the tropical regions that provide food, feed, stover (dry straw) and fuel to millions of poor farmer families and their livestock. It plays an important role as a major grain cum fodder crop. Sorghum crop provides excellent forage in dry land areas. Sorghum has four desirable qualities viz., high 
dry matter yield; light use; water use and nitrogen use efficiency. It is nutritious, juicy, palatable and well-liked by the cattle and can withstand high temperature and minimal soil moisture.

Forage quality is an important selection criterion in fodders especially so in fodder sorghum because the performance of dairy animals not alone depends on availability of fodder but on the continuous availability of quality forage in adequate amount. Therefore, the critical limitation on profitable animal production in developing countries is the insufficient availability of quality forage (Sarwar et al., 2002). Forage yield in quantity alone cannot measure the feeding value of the crops. So, the quality value of forages like palatability and nutritional value of forage must be determined for measuring the feed value. Protein content and digestibility of fodder are two important components for quality in fodder sorghum. Improving the nutritive value of forage sorghum for productive ruminants shall be achieved by increasing dry matter digestibility and reducing the lignin content. Such improvements can be accomplished through genetic breeding and selection, choosing the optimal stage for harvest and improving growth factors (Carmi et al., 2006). In this perspective, an effort has been made in the present investigation to explore the nutritive value and fodder potential of sorghum accessions to identify high biomass, nutrient rich quality fodder which is the need of the hour.

\section{Materials and Methods}

Twenty-four sorghum germplasm accessions viz., TKSV 1126, TKSV 1166, TKSV 1050, TKFS 1161, TKFS 11107, TKSV 1133, TKSV 1182, TKSV 1127, TNS 623, TKFS 1051, TKSV 1123, TKSV 1046, TKSV 1171, TKFS 1049, TKSV 1115, TKSV 1130, TKFS
11111, TKFS 1198, K 11, K 3, IS 18758, IS 18551, SPV 2123 and TAM 428 were used evaluating their fodder yield potential and nutritional quality. The accessions were raised in two replications along with the local check CO (FS) 29 in two rows of $4 \mathrm{~m}$ length per replication with a spacing of $45 \mathrm{~cm} \times 15 \mathrm{~cm}$ using randomized block design. All the recommended agronomic practices were followed during the entire crop period.

\section{Observations recorded}

Five plants were randomly selected and evaluated for fodder yield potential at days to 50 per cent flowering. The observations were recorded on plant height (PLH), stem girth (STG), number of tillers per plant (NOT), number of leaves per plant (NOL), leaf length (LEL), leaf breadth (LEB), leaf stem ratio (LSR), green fodder yield per plant (GFY) and dry fodder yield per plant (DFY).

For quality assessment plant samples were collected during panicle initiation and were chopped, air dried and finally oven dried at $60^{\circ} \mathrm{C}$ for two days. The oven dried samples were ground and sieved using different sieve sizes and utilized for the estimation of crude protein content (CPC), crude fibre content (CFC), crude ash content (CAC), ADF (Acid detergent Fibre), NDF (Neutral detergent fibre) and ether extract (EET). The traits nonfibre carbohydrates (NFC), nitrogen free extract (NFE), total digestible nutrients (TDN), digestible dry matter (DDM), dry matter intake (DMI), relative forage quality (RFQ) and metabolisable energy (MER) were derived using various equations (Appendix 1).

Grading systems viz., AFIA (Australian Fodder Industry Association) standards for cereal hay (AFIA, 2004) and the Southeastern forage quality categorization system (Dennis, 2011) was used to grade the accessions for their nutritional quality. 


\section{Statistical analysis}

Phenotypic and genotypic components of traits were worked out based on the formula given by Goulden (1952). Heritability in broad sense and genetic advance as per cent of means were worked out as per Allard (1960) and Johnson et al., (1955) respectively. Genotypic correlation coefficients were computed from the mean of traits over replications for all the characters keeping MER as the dependent variable by using formula given by Weber and Moorthy (1952). Correlation coefficients were compared against table $\mathrm{r}$ values at $(\mathrm{n}-2)$ degrees of freedom at the probability levels of 0.05 and 0.01 to test their significance (Panse and Sukhatme, 1961).

Diversity analysis was carried out to study clustering pattern of the accessions. Data of nine fodder yield and 13 quality parameters were subjected for multivariate hierarchical cluster analysis. Similarity matrix was generated using the SIMINT programme of NTSYS-pc software version 2.02i (Rohlf, 2005). Similarity coefficients were used for cluster analysis and dendrogram was constructed by UPGMA method (Sneath and Sokal, 1973).

\section{Results and Discussion}

The analysis of variance for the fodder yield traits and quality parameters showed significantly high differences among the genotypes for all the characters. This indicated the existence of abundant variability among the accessions studied.

\section{Per se performance}

Plant height is an important growth parameter which influences fodder quantity, quality and mostly shows relative vigour of the crop. Long slender fine stems are often preferred by animals than short thick stems as they affect palatability of the forage. K 3 which observed the highest mean of $346.10 \mathrm{~cm}$ for PLH did not differ significantly with K $11(324.10 \mathrm{~cm})$ and TKFS $1049(321.90 \mathrm{~cm})$. Correspondingly the tallest genotype $\mathrm{K} 3$ recorded high GFY $(1452.40 \mathrm{~g})$ and DFY (262.30g) but was significantly on par with TKSV 1050 (1409.5g and 213.35g). It is evident from the results that if there has been higher GFY, there would be higher DFY (Table 1). The results obtained were in parallel with Yousef et al., (2009), Simili et al., (2010) and Palta and Karadavut, (2011).

Green leaves contribute much to the forage quality. The accession TKFS 1198 observed high mean performance for the traits NOL (13.60), LEL $(92.90 \mathrm{~cm})$ and LSR (0.26). Tall plants produce more number of leaves and vice-versa. This was obvious from our results. Accession K 11, with a mean PLH of $324.10 \mathrm{~cm}$ registered high NOL of 12.80 , while the genotype TKSV 1046 which recorded a low mean PLH $(136.80 \mathrm{~cm})$ obtained a low mean NOL of 9.20. Similar significant differences among sorghum cultivars were also reported by Naeem et al., (2002) and Nabi et al., (2006).

Crude protein content is of utmost importance as it largely determines the palatability and digestibility of forage crops. The genotype TKSV 1171 recorded highest CPC (12.78\%) but was on par with the genotypes TKSV 1182, TKSV 1126, TKFS 1161, TKSV 1166 and TKFS 11111 with mean CPC of 12.43 , $11.94,11.73,10.61$ and $10.47 \%$, respectively. The difference among genotypes may be due to relative contribution of leaves to total biomass and concentration of protein in dry fodder (Table 2). The significant differences in crude protein content among various sorghum genotypes have also been reported by Filho et al., (2004), Nabi et al., (2006) and Tauqir et al., (2009). Conversely, in the 
present study the genotype TKSV 1171 which showed high CPC obtained low LSR. Therefore, this genotype could be improved through hybridization programmes to increase the leaf count and simultaneously the leafstem ratio which would reflect on achieving more protein content.

Fat content (EET) was high in TKSV 1133 $(4.49 \%)$ and was statistically on par with TKFS 1161 (4.14\%) and TKSV 1126 $(4.13 \%)$. The high level of fat observed here would be beneficial to the feed industry, because fat is a major source of energy. Inversely, higher fat content could decrease the palatability of the diet by coating the fibre which would also affect the digestibility of the feed (John, 2005). The genotypes TKSV 1133, TKFS 1161 and TKSV 1126 recorded high fat content and also exhibited high significance for digestibility and dry matter intake. The accession, TKSV 1126 which recorded high DDM (66.31\%), DMI (2.18\%) and MER (11.41 MJ ME/kg DM) would be a desirable donor for use in quality improvement programme to obtain high fat content with better palatability and digestibility.

Presence of high level of fibre portions in the fodder material adversely affects the forage quality. Higher the fibre content lower is the digestibility and moreover, fibre portion increases with the age of the plant. The genotype TKSV 1127 exhibited high mean CFC of $30.10 \%$ whereas IS 18551 and TKSV 1126 recorded low mean CFC of 18.75 and $19.75 \%$, respectively. Acid detergent fibre was minimum in TKSV 1126 (29.00\%) and maximum in three genotypes viz., TKSV 1127 (41.00\%), TKFS 1049 (41.00\%) and TKFS 1198 (41.00\%). Neutral detergent fibre ranged from 55.00 (TKSV 1126) and 72.00 (SPV 2123) per cent. Similar reports by Marsalis et al., (2010), Machado et al., (2011), Barba et al., (2012) and Matos et al.,
(2014) supported our findings. Lower the ADF, the feed is highly digestible (i.e., of high quality) and lower NDF leads to higher intakes (John, 2005). Considering the above facts, the genotype TKSV 1126 was identified as good quality forage (high nutrient content; palatability; digestibility and intake rate) owing to reduced fibre portions.

Non-fibre carbohydrates (starch, sugar and pectin) are the non-cell wall carbohydrates which are digested faster than structural carbohydrates and fused instantly by the microbes in the rumen. Highest mean for this trait was exhibited by TNS 623 (24.34\%). Higher the proportion of NFC more will be the nutritive value. Conversely, in our findings, TNS 623 recorded low mean CPC of $6.90 \%$ though having higher intake and digestibility rates.

Digestibility (DDM) and Energy (MER) are closely linked to vegetative stage. Young leaves have higher DDM and MER levels. The energy that is absorbed by the cow after the loss of some gross energy is known as Metabolisable Energy (MER). It is the energy used for maintenance of body systems, activity, milk production, pregnancy and weight gain, higher the value, better the quality of the feed. Furthermore, the digestibility rate and the energy synthesized declines sharply once heading starts. The accession TKSV 1126 recorded the highest mean for DDM of $66.31 \%$, while the genotype TNS 623 observed high mean MER of $11.97 \%$. Our results were in accordance with the findings reported by Mizubuti et al., (2002) and Barba et al., (2012).

Overall, the accession K 3 expressed high fodder potential owing to high significant mean performance for most of the yield traits viz., PLH, NOT, GFY and DFY. On the quality front, the accession TKSV 1126 was exceptional in nutritional value with high 
protein and low fibre portions leading to high digestibility and intake rates combined with high metabolisable energy.

\section{Variability parameters}

The estimates of PCV were greater than their corresponding GCV for all the fodder yield and quality parameters (Table 3) denoting environmental factors influencing their expression to some degree or the other (Ghorade et al., 2015). Broad sense heritability ranged from 33.34 (LEB) to 99.91 per cent (NOL) for fodder yield traits and 78.92 (CFC) and 99.40 per cent (EET) among the quality parameters. High heritability was observed for all the fodder yield and quality traits indicating that these characters would respond positively to selection because of their broad sense heritability except leaf width $(33.34 \%)$ which showed a moderate estimate of heritability. Fodder yield traits viz., NOT, DFY, GFY, PLH, LSR and NOL and quality parameters such as EET, NFC, CPC and CAC exhibited high expected genetic advance per cent over mean.

High GCV, heritability and genetic advance as per cent of mean was recorded by NOL, EET, DFY and GFY which indicates that these characters are controlled by additive gene action and phenotypic selection for these characters would be effective for fodder improvement.

\section{Correlation analysis}

Knowledge of association between yield and its component traits and among the component parameters themselves can improve the efficiency of selection in plant breeding. When there is positive association of major yield characters and its components, breeding would be very effective. But when these characters are negatively associated, it would be difficult to exercise simultaneous selection for them in developing a variety (Nemati et al., 2009).

Correlation analysis among the fodder yield and quality parameters with MER as the dependent variable observed the traits GFY and DMY having positive significant association (Appendix 2) with PLH, NOT, $\mathrm{CFC}, \mathrm{ADF}$ and NDF and between themselves. Leaf length showed positive and highly significant association with NFC, NFE and TDN. ADF obtained a perfect negative correlation for DDM. Another significant association was observed between NDF and DMI. The quality improving traits (NFC, NFE, TDN, DDM, DMI, RFQ and MER) observed significant positive association within themselves.

The traits PLH, NOT, NOL and LSR were positively and significantly associated with GFY and DFY. When the number of leaves is many, there will be a greater surface area for photosynthesis; greater photosynthesis can translate into more photosynthates, ultimately resulting in increased fodder yield (Alhassan et al., 2008). This is evident from our results (Appendix 2). It is also noticed that the characters that exhibited positive associations with fodder yield have also showed positive associations among themselves.

The traits representing fibre portions viz., CFC, ADF and NDF had a strong positive significant association within themselves. Correlation among the above three traits were very high. It was also noticed that the trait CFC showed negative and highly significant association with NFC, NFE, TDN, DDM, DMI, RFQ and MER. Likewise, ADF observed significant negative associations with CPC, NFC, DMI and RFQ, while it showed a perfect negative relationship with DDM inferring that high ADF causes poor digestibility (John, 2005). Similarly, NDF observed highly significant negative 
association with DMI deducing that high NDF leads to poor intake rates (John, 2005). This indicated that when fibre content is high, the nutrient content will be low; digestibility and palatability will be poor, ultimately resulting in poor intake due to poor forage quality. Moreover, the presence of higher portion of structural carbohydrates (Pectin, cellulose, hemicellulose, lignin and silica) in the forage will seriously affect the digestibility of the fodder.

Non-fibre carbohydrates had positive and significant association with LEL, NFE, TDN, DDM, DMI, RFQ and MER evidencing that when the fibre content is very low in the feed there is higher palatability, intake and digestibility, eventually resulting in higher metabolisable energy and superior forage quality.

The trait TDN, which encompasses the digestible crude protein, crude fat, crude fibre and nitrogen free extract observed positive and a perfect correlation with MER signifying the need of nutrients for obtaining higher energy. Hence, genotypes that deliver high energy can be alternatively selected using TDN and vice-versa.

Our data also revealed some interesting associations such as GFY showing positive significant association with CFC, DDM, DMI, RFQ and significant negative correlation with CPC and LSR. These associations infer that stem weight might have contributed to a higher ratio to the overall GFY. Therefore, resulting in lower quality fodder as stems contribute majority of the fibre portions.

\section{Genetic diversity}

As suggested by Rohlf (2005), the accessions were grouped into different clusters based on the coefficient values. The accessions were grouped into five clusters at the coefficient of
0.15 (Fig. 1). Among the clusters, cluster I was the largest comprising seven accessions followed by cluster IV with six accessions. Cluster V formed the smallest group with three accessions.

Discernible variations were observed among the formed clusters. Based on the cluster mean (Table 4), cluster $\mathrm{V}$ observed high cluster mean for PLH $(311.63 \mathrm{~cm})$, LEL $(88.07 \mathrm{~cm})$, GFY (1254.92g), DFY (200.82g), NFC (17.09\%), NFE (54.96\%), TDN (70.35\%) and MER (11.12 MJ/kg DM), whereas cluster II exhibited high mean for most of the quality parameters such as high CPC (9.90\%), EET (2.99\%), CAC (11.25\%), DDM (62.22\%), DMI (2.01\%) and RFQ (113.62). The accessions viz., TKSV 1050, K 11 and TKFS 1049 which formed cluster V and the accessions, TKFS 1161, TKSV 1171, TNS 623 and TKSV 1046 could be utilized in back crossing programmes as donors for transferring traits of interest.

\section{Grading for quality estimates}

Fodder quality represents the ability of the cow to digest and utilize the nutrient components present in the source. Higher the amount and digestibility of nutrients; more will be the fodder quality. Fodder with high quality and digestibility contains lowest amount of structural carbohydrates (cellulose, hemicellulose) and lignin. The accessions were graded as per AFIA standards and Southeastern forage quality categorization system (Table 5). Based on AFIA standards, the accession TKSV 1126 gained the highest grade of 'A1', while four accessions viz., TKSV 1127, TKFS 1049, SPV 2123 and TAM 428 attained the lowest grade of 'C3'. On the basis of AFIA standards, TKSV 1126 exhibited superior quality (A1 grade). The high relative fodder quality value signifies its superior quality and that it can be utilized for improving the quality attributes. 
Table.1 Mean performance of 24 sorghum accessions for fodder yield traits

\begin{tabular}{|c|c|c|c|c|c|c|c|c|c|}
\hline Accessions & PLH & STG & NOT & NOL & LEB & LEL & LSR & GFY & DFY \\
\hline TKSV 1126 & 200.8 & 1.5 & 1.0 & 9.4 & 8.8 & 76.3 & 0.2 & 566.6 & 79.2 \\
\hline TKSV 1166 & 176.8 & 1.6 & 1.0 & 9.8 & 9.2 & 77.9 & 0.2 & 516.7 & 76.2 \\
\hline TKSV 1050 & 288.9 & 1.7 & 4.2 & 10.4 & 9.9 & 89.0 & 0.2 & 1409.5 & 213.4 \\
\hline TKFS 1161 & 168.1 & 1.7 & 1.0 & 9.6 & 9.0 & 75.1 & 0.2 & 358.8 & 51.7 \\
\hline K 11 & 324.10 & 1.50 & 2.60 & 12.80 & 7.90 & 87.10 & 0.20 & 1131.50 & 210.77 \\
\hline TKFS 11107 & 296.70 & 1.52 & 1.60 & 13.00 & 9.38 & 84.40 & 0.20 & 887.10 & 122.45 \\
\hline TKSV 1133 & 170.00 & 1.88 & 1.00 & 10.00 & 8.92 & 81.10 & 0.26 & 583.37 & 110.77 \\
\hline TKSV 1182 & 175.60 & 1.92 & 1.00 & 9.80 & 8.92 & 66.00 & 0.24 & 691.53 & 68.74 \\
\hline TKSV 1127 & 229.60 & 1.68 & 1.00 & 12.20 & 9.06 & 71.90 & 0.24 & 744.40 & 112.45 \\
\hline TNS 623 & 209.00 & 1.64 & 1.00 & 10.40 & 9.44 & 86.20 & 0.24 & 575.27 & 100.69 \\
\hline TKFS 1051 & 287.90 & 1.70 & 3.40 & 13.40 & 8.22 & 70.20 & 0.17 & 1117.07 & 204.92 \\
\hline TKSV 1123 & 197.60 & 2.26 & 1.00 & 11.60 & 9.36 & 82.30 & 0.22 & 858.80 & 128.35 \\
\hline TKSV 1046 & 136.80 & 1.86 & 1.00 & 9.20 & 8.50 & 75.40 & 0.19 & 437.67 & 63.67 \\
\hline TKSV 1171 & 217.70 & 2.28 & 1.00 & 9.80 & 9.54 & 70.50 & 0.20 & 443.63 & 51.19 \\
\hline TKFS 1049 & 321.90 & 1.70 & 2.60 & 10.80 & 8.04 & 88.10 & 0.15 & 1223.80 & 178.35 \\
\hline K 3 & 346.10 & 1.72 & 3.60 & 11.20 & 9.02 & 80.10 & 0.20 & 1452.40 & 262.30 \\
\hline TKSV 1115 & 198.40 & 2.24 & 1.00 & 12.20 & 8.92 & 78.50 & 0.21 & 777.40 & 111.65 \\
\hline TKSV 1130 & 197.10 & 1.96 & 1.00 & 12.60 & 9.36 & 77.30 & 0.24 & 725.23 & 89.22 \\
\hline TKFS 11111 & 279.40 & 2.18 & 2.00 & 9.80 & 9.52 & 82.70 & 0.12 & 1137.90 & 222.58 \\
\hline TKFS 1198 & 288.90 & 1.82 & 1.80 & 13.60 & 8.04 & 92.90 & 0.26 & 850.90 & 167.55 \\
\hline SPV 2123 & 239.20 & 1.62 & 1.00 & 12.80 & 9.62 & 73.40 & 0.17 & 1194.33 & 176.55 \\
\hline IS 18758 & 187.00 & 2.00 & 1.00 & 12.40 & 9.32 & 80.80 & 0.28 & 699.47 & 105.13 \\
\hline IS 18551 & 255.80 & 1.96 & 1.00 & 10.80 & 10.24 & 88.20 & 0.20 & 733.60 & 87.76 \\
\hline TAM 428 & 210.00 & 1.94 & 2.20 & 12.20 & 9.40 & 85.10 & 0.23 & 768.10 & 160.75 \\
\hline Grand mean & 233.48 & 1.83 & 1.63 & 11.24 & 9.07 & 80.02 & 0.21 & 828.54 & 131.51 \\
\hline SEd & 10.61 & 0.11 & 0.02 & 0.55 & 0.45 & 2.99 & 0.02 & 51.07 & 7.84 \\
\hline CD (0.05) & 21.08 & 0.23 & 0.04 & 1.08 & $\mathbf{0 . 8 8}$ & 5.93 & $\mathbf{0 . 0 3}$ & 101.44 & 15.56 \\
\hline $\mathrm{CV} \%$ & 7.19 & 9.91 & 1.76 & 7.67 & 7.77 & 5.90 & 11.57 & 9.75 & 9.42 \\
\hline
\end{tabular}


Table.2 Mean performance of 24 sorghum accessions for quality parameters

\begin{tabular}{|c|c|c|c|c|c|c|c|c|c|c|c|c|c|}
\hline Accessions & CFC & CPC & EET & CAC & ADF & NDF & NFC & NFE & TDN & DDM & DMI & RFQ & MER \\
\hline TKSV 1126 & 19.8 & 11.9 & 4.1 & 10.0 & 29.0 & 55.0 & 18.9 & 54.2 & 71.9 & 66.3 & 2.2 & 127.5 & 11.4 \\
\hline TKSV 1166 & 22.1 & 10.6 & 3.4 & 10.0 & 33.0 & 58.0 & 18.0 & 53.9 & 70.6 & 63.2 & 2.1 & 118.8 & 11.2 \\
\hline TKSV 1050 & 25.0 & 9.9 & 3.1 & 10.0 & 36.0 & 62.0 & 15.0 & 52.0 & 68.8 & 60.9 & 1.9 & 108.3 & 10.8 \\
\hline TKFS 1161 & 22.1 & 11.7 & 4.1 & 11.0 & 33.0 & 59.0 & 14.1 & 51.0 & 69.4 & 63.2 & 2.0 & 114.8 & 11.0 \\
\hline K 11 & 24.45 & 8.72 & 3.79 & 9.00 & 34.00 & 59.00 & 19.49 & 54.04 & 71.10 & 62.41 & 2.03 & 117.57 & 11.26 \\
\hline TKFS 11107 & 26.40 & 8.40 & 2.74 & 9.00 & 39.00 & 70.00 & 9.86 & 53.46 & 69.39 & 58.52 & 1.71 & 96.71 & 10.95 \\
\hline TKSV 1133 & 21.60 & 9.52 & 4.49 & 9.00 & 32.00 & 59.00 & 17.99 & 55.39 & 73.00 & 63.97 & 2.03 & 120.71 & 11.61 \\
\hline TKSV 1182 & 24.50 & 12.43 & 3.77 & 9.00 & 35.00 & 63.00 & 11.81 & 50.31 & 69.11 & 61.64 & 1.90 & 107.02 & 10.89 \\
\hline TKSV 1127 & 30.10 & 7.14 & 3.07 & 11.00 & 41.00 & 70.00 & 8.79 & 48.69 & 65.80 & 56.96 & 1.71 & 91.71 & 10.28 \\
\hline TNS 623 & 21.60 & 6.90 & 3.77 & 8.00 & 33.00 & 57.00 & 24.34 & 59.74 & 74.94 & 63.19 & 2.11 & 128.27 & 11.97 \\
\hline TKFS 1051 & 28.00 & 8.30 & 3.42 & 14.00 & 39.00 & 66.00 & 8.29 & 46.29 & 64.01 & 58.52 & 1.82 & 94.61 & 9.95 \\
\hline TKSV 1123 & 25.45 & 9.73 & 3.08 & 10.00 & 37.00 & 65.00 & 12.19 & 51.74 & 68.58 & 60.08 & 1.85 & 102.94 & 10.80 \\
\hline TKSV 1046 & 21.60 & 8.19 & 1.33 & 13.00 & 34.00 & 56.00 & 21.48 & 55.88 & 68.34 & 62.41 & 2.14 & 119.06 & 10.75 \\
\hline TKSV 1171 & 23.55 & 12.78 & 2.73 & 13.00 & 37.00 & 69.00 & 2.50 & 47.95 & 65.30 & 60.08 & 1.74 & 92.33 & 10.19 \\
\hline TKFS 1049 & 24.00 & 6.86 & 1.33 & 9.00 & 41.00 & 66.00 & 16.81 & 58.81 & 71.14 & 56.96 & 1.82 & 105.16 & 11.27 \\
\hline K 3 & 25.50 & 7.95 & 1.68 & 10.00 & 37.00 & 70.00 & 10.38 & 54.88 & 68.78 & 60.08 & 1.71 & 95.86 & 10.83 \\
\hline TKSV 1115 & 24.00 & 9.98 & 1.68 & 10.00 & 35.00 & 61.00 & 17.35 & 54.35 & 68.74 & 61.64 & 1.97 & 109.94 & 10.83 \\
\hline TKSV 1130 & 22.55 & 9.45 & 1.68 & 11.00 & 31.00 & 56.00 & 21.87 & 55.32 & 69.08 & 64.75 & 2.14 & 120.35 & 10.89 \\
\hline TKFS 11111 & 24.95 & 10.47 & 0.63 & 10.00 & 30.00 & 60.00 & 18.90 & 53.95 & 67.30 & 65.53 & 2.00 & 109.43 & 10.56 \\
\hline TKFS 1198 & 24.00 & 9.10 & 1.68 & 7.00 & 41.00 & 62.00 & 20.22 & 58.22 & 72.01 & 56.96 & 1.94 & 113.32 & 11.43 \\
\hline SPV 2123 & 23.05 & 7.84 & 1.68 & 10.00 & 40.00 & 72.00 & 8.48 & 57.43 & 70.52 & 57.74 & 1.67 & 95.55 & 11.16 \\
\hline IS 18758 & 21.60 & 8.30 & 1.68 & 13.00 & 35.00 & 65.00 & 12.03 & 55.43 & 68.46 & 61.64 & 1.85 & 102.76 & 10.78 \\
\hline IS 18551 & 18.75 & 9.84 & 2.38 & 12.00 & 33.00 & 58.00 & 17.79 & 57.04 & 70.91 & 63.19 & 2.07 & 119.27 & 11.23 \\
\hline TAM 428 & 22.55 & 7.77 & 0.63 & 9.00 & 40.00 & 63.00 & 19.60 & 60.05 & 71.30 & 57.74 & 1.90 & 110.42 & 11.30 \\
\hline Grand mean & 23.63 & 9.33 & 2.58 & 10.29 & 35.63 & 62.54 & 15.26 & 54.17 & 69.52 & 61.15 & 1.93 & 109.27 & 10.97 \\
\hline SEd & 1.04 & 0.53 & 0.07 & 0.62 & 1.27 & 1.81 & 1.94 & 1.28 & 0.92 & 1.00 & 0.06 & 3.81 & 0.17 \\
\hline CD (0.05) & 2.09 & 1.07 & 0.15 & 1.25 & 2.56 & 3.65 & 3.90 & 2.58 & 1.85 & 2.01 & 0.11 & 7.66 & 0.34 \\
\hline CV \% & 5.38 & 7.01 & 3.46 & 7.36 & 4.38 & 3.55 & 15.57 & 2.89 & 1.62 & $2 . .00$ & 3.61 & 4.27 & 1.90 \\
\hline
\end{tabular}


Int.J.Curr.Microbiol.App.Sci (2017) 6(8): 898-911

Fig.1 Dendrogram for sorghum accessions derived by UPGMA from the dissimilarity matrix

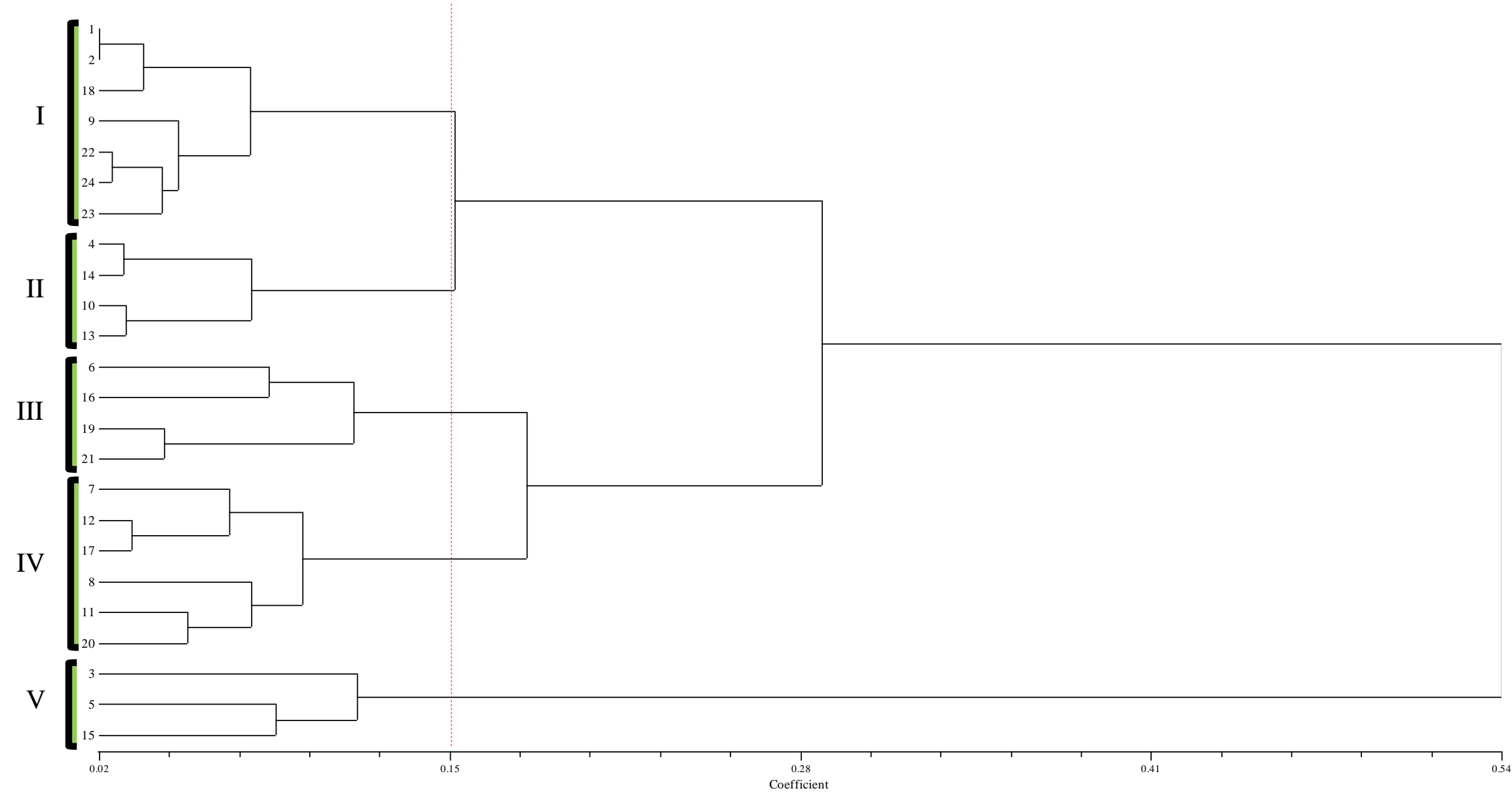


Table.3 Mean, range and variability parameters for the fodder yield and quality traits

\begin{tabular}{|c|c|c|c|c|c|c|c|}
\hline \multirow{2}{*}{ Traits } & \multirow{2}{*}{$\begin{array}{c}\text { Grand } \\
\text { mean }\end{array}$} & \multicolumn{2}{|c|}{ Mange } & $\begin{array}{c}\text { Phenotypic } \\
\text { coefficient of } \\
\text { variation (\%) }\end{array}$ & $\begin{array}{c}\text { Genotypic } \\
\text { coefficient of } \\
\text { variation (\%) }\end{array}$ & $\begin{array}{c}\text { Heritability } \\
\text { (\%) }\end{array}$ & $\begin{array}{c}\text { Expected } \\
\text { genetic } \\
\text { advance \% } \\
\text { of mean }\end{array}$ \\
\hline PLH & 233.5 & 136.8 & 346.1 & 25.6 & 24.6 & 92.1 & 48.6 \\
\hline STG & 1.8 & 1.5 & 2.3 & 15.7 & 12.2 & 60.2 & 19.5 \\
\hline NOT & 1.6 & 1.0 & 4.2 & 60.0 & 60.0 & 99.9 & 123.5 \\
\hline NOL & 11.2 & 9.2 & 13.6 & 14.4 & 12.1 & 71.4 & 21.1 \\
\hline LEB & 9.1 & 7.9 & 10.2 & 9.5 & 5.5 & 33.3 & 6.5 \\
\hline LEL & 80.0 & 66.0 & 92.9 & 10.1 & 8.2 & 65.9 & 13.7 \\
\hline LSR & 0.2 & 0.1 & 0.3 & 20.1 & 16.5 & 66.9 & 27.7 \\
\hline GFY & 828.6 & 358.8 & 1452.4 & 38.1 & 36.8 & 93.5 & 73.4 \\
\hline DFY & 131.5 & 51.2 & 262.3 & 46.7 & 45.7 & 95.9 & 92.3 \\
\hline CFC & 23.6 & 18.8 & 30.1 & 11.5 & 10.1 & 78.9 & 18.4 \\
\hline CPC & 9.3 & 6.9 & 12.8 & 19.1 & 17.8 & 86.5 & 34.0 \\
\hline EET & 2.6 & 0.6 & 4.5 & 44.8 & 44.6 & 99.4 & 91.7 \\
\hline CAC & 10.3 & 7.0 & 14.0 & 17.6 & 16.0 & 82.6 & 30.0 \\
\hline ADF & 35.6 & 29.0 & 41.0 & 10.7 & 9.8 & 83.3 & 18.4 \\
\hline NDF & 62.5 & 55.0 & 72.0 & 8.6 & 7.9 & 83.1 & 14.8 \\
\hline NFC & 15.3 & 2.5 & 24.3 & 37.5 & 34.1 & 82.8 & 63.9 \\
\hline NFE & 54.2 & 46.3 & 60.1 & 7.0 & 6.4 & 83.1 & 12.1 \\
\hline TDN & 69.5 & 64.0 & 74.9 & 3.8 & 3.4 & 81.6 & 6.3 \\
\hline DDM & 61.2 & 57.0 & 66.3 & 4.8 & 4.4 & 82.5 & 8.2 \\
\hline DMI & 1.9 & 1.7 & 2.2 & 8.6 & 7.8 & 82.2 & 14.5 \\
\hline RFQ & 109.3 & 91.7 & 128.3 & 10.7 & 9.8 & 84.0 & 18.5 \\
\hline MER & 11.0 & 10.0 & 12.0 & 4.4 & 4.0 & 81.5 & 7.4 \\
\hline
\end{tabular}


Table.4 Cluster mean for various fodder yield and quality traits and entries forming various clusters

\begin{tabular}{|c|c|c|c|c|c|}
\hline \multirow{2}{*}{ Traits } & \multicolumn{5}{|c|}{ Cluster mean } \\
\hline & I & II & III & IV & $\mathbf{V}$ \\
\hline PLH & 208.16 & 182.90 & 290.35 & 219.73 & 311.63 \\
\hline STG & 1.81 & 1.87 & 1.76 & 1.97 & 1.64 \\
\hline NOT & 1.17 & 1.00 & 2.05 & 1.53 & 3.13 \\
\hline NOL & 11.34 & 9.75 & 11.70 & 11.77 & 11.33 \\
\hline LEB & 9.34 & 9.13 & 9.39 & 8.73 & 8.60 \\
\hline LEL & 79.64 & 76.80 & 80.15 & 78.50 & 88.07 \\
\hline LSR & 0.24 & 0.21 & 0.17 & 0.23 & 0.19 \\
\hline GFY & 679.16 & 453.84 & 1167.93 & 813.18 & 1254.92 \\
\hline DFY & 101.53 & 66.81 & 195.97 & 132.00 & 200.82 \\
\hline CFC & 22.49 & 22.21 & 24.98 & 24.59 & 24.47 \\
\hline CPC & 9.29 & 9.90 & 8.67 & 9.84 & 8.51 \\
\hline EET & 2.43 & 2.99 & 1.68 & 3.02 & 2.73 \\
\hline CAC & 10.86 & 11.25 & 9.75 & 9.83 & 9.33 \\
\hline ADF & 34.57 & 34.25 & 36.50 & 36.50 & 37.00 \\
\hline NDF & 60.71 & 60.25 & 68.00 & 62.67 & 62.33 \\
\hline NFC & 16.71 & 15.61 & 11.91 & 14.64 & 17.09 \\
\hline NFE & 54.94 & 53.65 & 54.93 & 52.72 & 54.96 \\
\hline TDN & 69.72 & 69.51 & 69.00 & 69.24 & 70.35 \\
\hline DDM & 61.97 & 62.22 & 60.47 & 60.47 & 60.08 \\
\hline DMI & 1.99 & 2.01 & 1.77 & 1.92 & 1.93 \\
\hline RFQ & 112.97 & 113.62 & 99.39 & 108.09 & 110.34 \\
\hline MER & 11.01 & 10.97 & 10.88 & 10.92 & 11.12 \\
\hline $\begin{array}{l}\text { Cluster } \\
\text { entries }\end{array}$ & $\begin{array}{c}\text { TKSV } 1126 \\
\text { TKSV } 1166 \\
\text { TKSV } 1130 \\
\text { TKSV } 1127 \\
\text { IS 18758, TAM } 428 \\
\text { IS } 18551 \\
\end{array}$ & $\begin{array}{c}\text { TKFS } 1161 \\
\text { TKSV } 1171 \\
\text { TNS } 623 \\
\text { TKSV } 1046\end{array}$ & $\begin{array}{c}\text { TKFS } 11107 \\
\text { K } 3 \\
\text { TKFS } 11111 \\
\text { SPV } 2123\end{array}$ & $\begin{array}{l}\text { TKSV } 1133 \\
\text { TKSV } 1123 \\
\text { TKSV } 1115 \\
\text { TKSV } 1182 \\
\text { TKFS } 1051 \\
\text { TKFS } 1198 \\
\end{array}$ & $\begin{array}{c}\text { TKSV } 1050 \\
\text { K } 11 \\
\text { TKFS } 1049\end{array}$ \\
\hline
\end{tabular}


Table.5 AFIA grade and RFQ category of the accessions

\begin{tabular}{|l|c|c|}
\hline Accession No. & AFIA grade & RFQ Category \\
\hline TKSV 1126 & A1 & Good \\
\hline TKSV 1166 & B1 & Good \\
\hline TKSV 1050 & B2 & Fair \\
\hline TKFS 1161 & B1 & Good \\
\hline K 11 & B2 & Good \\
\hline TKFS 11107 & C2 & Fair \\
\hline TKSV 1133 & B2 & Good \\
\hline TKSV 1182 & B1 & Fair \\
\hline TKSV 1127 & C3 & Fair \\
\hline TNS 623 & B3 & Good \\
\hline TKFS 1051 & C2 & Fair \\
\hline TKSV 1123 & B2 & Fair \\
\hline TKSV 1046 & B2 & Good \\
\hline TKSV 1171 & B1 & Fair \\
\hline TKFS 1049 & C3 & Fair \\
\hline K 3 & B3 & Fair \\
\hline TKSV 1115 & B2 & Fair \\
\hline TKSV 1130 & B2 & Good \\
\hline TKFS 11111 & B1 & Fair \\
\hline TKFS 1198 & C2 & Good \\
\hline SPV 2123 & C3 & Fair \\
\hline IS 18758 & B2 & Fair \\
\hline IS 18551 & B2 & Good \\
\hline TAM 428 & C3 & Good \\
\hline
\end{tabular}

On the basis of Southeastern forage quality categorization systems, none of the accessions fell under the group premium with a RFQ value above 140. However, 11 accessions were categorized as good quality forage with the accession TNS 623 having the highest RFQ value of 128.27 followed by TKSV 1126 (127.5). Thirteen accessions fell in the fair quality category with TKSV 1127 recording the lowest RFQ value of 91.71.

In conclusion, under the light of present study, the superiority of K 3 and TKSV 1050 for fresh and dry fodder yield over the local check CO (FS) 29 suggests their adoption for general cultivation. Moreover, the genotype
TKSV 1126 which ranked top with its dry matter having the best nutritional value, high intake and digestibility rates could be used for quality improvement to transfer desirable traits to high yielding genotypes through back crossing programme. Hybridization could be attempted between lines having high yield potential and nutritional quality to develop genotypes possessing rich nutritional fodder which is the demand of the present era.

\section{Abbreviations}

PLH-Plant height, STG-Stem girth, NOTNumber of tillers per plant, NOL-Number of leaves per plant, LEL-Leaf length, LEB-Leaf 
breadth, LSR-Leaf-stem ratio, GFY-Green fodder yield per plant, DFY-Dry fodder yield per plant.

\section{References}

AFIA. 2004. Fodders. Trading Standards. Australian Fodder Industry Association Standards.

Alhassan, U., Yeye, M.Y., Aba, D.A. and Alabi, S.O. 2008. Correlation and path coefficient analyses for agronomic and malting quality traits in some sorghum [Sorghum bicolor (L.) Moench] genotypes. J. Food Agric. Environ., 6(4): 285-288.

Allard, R.W. 1960. Principles of Plant Breeding. John Wiley and Sons, Inc., New York. p.485.

Barba, L.F.P., Ferreira, M.A., Guim, A., Tabosa, J.N., Gomes, L.H.S. and Santos, V.L.C. 2012. Nutritive value of different silage sorghum (Sorghum bicolor L. Moench) cultivares. Acta Scientiarum. Anim. Sci., Maringa, 34(2): 123-129.

Carmi, A., Aharoni, Y., Edelstein, M., Umiel, N., Hagiladi, A., Yosef, E., Nikbachat, M., Zenou, A. and Miron, J. 2006. Effects of irrigation and plant density on yield composition and in vitro digestibility of a new forage sorghum variety, Tal, at two maturity stages. Anim. Feed. Sci. Tech., 131: 120-133.

Dennis, W.H. 2011. Using Relative Forage Quality to categorize hay. Cooperative extension. The University of Georgia.

Dikshit, A.K. and Birthal, P.S. 2010. India's livestock feed demand: estimates and projections. Agric. Econ. Res. Rev., 23: 15-28.

Filho, C.J.D.A., Monterior, M.C.D., Oliverira, F.I.D., Tabosa, I.N., Bastos, G.Q. and Reis, O.Y.D. 2004. Dry matter yield and contents of crude protein in genotypes of forage sorghum.
Agropecuaria Tecnia, 25: 59-63.

Ghorade, R.B., Kalpande, V.V. and Sonone, C.V. 2015. Variability studies for biometrical parameters in kharif sorghum. Plant Arch., 15(1): 201-203.

Goulden, C.H. 1952. Methods of statistical analysis. John Wiley and Sons, Inc., New York.

John, M. 2005. Tropical dairy farming: feeding management for small holder dairy farming in the humid tropics. p. 312.

Johnson, H.W., Robinson, J.F. and Comstock, R.E. 1955. Estimates of genetic and environmental variability in soybean. Agron. J., 47: 314-318.

Machado, F.S., Rodríguez, N.M., Gonçalves, L.C., Rodrigues, J.A.S., Ribas, M.N., Possas, F.P., Guimaraes, Jr. R., Jayme, D.G. and Pereira, L.G.R. 2011. Consumo e digestibilidadeaparente de silagens de sorgo emdiferentesestádios de maturação. Arq. Bras. Med. Vet. Zootec., 63: 1470-1478.

Marsalis, M.A., Angadi, S.V. and ContrerasGovea, F.E. 2010. Dry matter yield and nutritive value of corn, forage sorghum and BMR forage sorghum at different plant populations and nitrogen rates. Field Crop. Res., 116: 52-57.

Matos, T.A., Gabriel de Oliveira, R.B., Velasco, F.O., Wilson, G.F.J., Rodriguez, N.M., Rodrigues, J.A.S., McAllister, T. and Goncalves, L.C. 2014. Intake and digestibility of sorghum (Sorghum bicolor, L. Moench) silages with different tannin contents in sheep. Rev. Bras. Zootec., 43(1): 14-19.

Mizubuti, I.Y., Ribeiro, E.L.A., Rocha, M.A., Silva, L.D.F., Pinto, A.P., Fernandes, W.C. and Rolim, M.A. 2002. Consumo e digestibilidadeaparente das silagens de milho (Zea mays L.), sorgo (Sorghum bicolor L. Moench.) e girassol (Helianthus annuus L). Rev. Bras. Zootec., 31(1): 267-272. 
Nabi, C.G., Riaz, M. and Ahmad, G. 2006. Comparison of some advanced lines of Sorghum bicolor L. Moench for green fodder/dry matter yields and morphoeconomic parameters. J. Agric. Res., 44(3).

Naeem, M., Chauhan, S.M., Khan, A.H. and Salahudin, S. 2002. Evaluation of different varieties of sorghum for green fodder yield potential. Asian J. Pl. Sci., 1: $142-143$.

Nemati, A., Sedghi, M., Sharifi, R.S. and Seiedi, M.N. 2009. In-vestigation of correlation between traits and path analysis of corn (Zea mays L.) grain yield at the climate of Ardabil region (Northwest Iran). Not. Bot. Hort. Agrobot. Cluj., 37(1): 194-198.

Palta, C. and Karadavut, U. 2011. Shoot growth curve analysis of maize cultivars under boron deficiency. J. Anim. Pl. Sci. 21(4): 696-699.

Panse, V.C. and Sukhatme P.V. 1961. Statistical Methods for Agricultural Workers. Indian Council of Agricultural Research, Publication, New Delhi p. 359.

Rohlf, F.J. NTsyspc. 2005. Numerical taxonomy and multivariate analysis system, version 2.02. Exeter software, Setauket, New York.

Sarwar, M., Khan, M.A. and Iqbal, Z. 2002.
Feed resources for livestock in Pakistan: Status Paper. Int. J. Agric. Biol., 4: 186192.

Simili, F.F., Gomide, C.A.M. and Moreira, A.L. 2010. Respostas do híbrido de sorgo-sudãoàsa dubações nitrogenada $\mathrm{e}$ potássica: Característica sestruturais e produtivas. Cienc. Agrotec., Lavras. 34(1): 87-94.

Sneath, P.H.A. and Sokal, R.R. 1973. Numerical Taxonomy. Freeman. San Francisco. Pp. 573.

Tauqir, N.A., Sarwar, M., Jabbar, M.A. and Mahmood, S. 2009. Nutritive value of jumbo grass (Sorghum bicolour Sorghum sudanefe) silage in lactating nili- ravi buffaloes. Pak. Vet. J., 29: 510.

Weber, C.R. and Moorthy, B.R. 1952. Heritable and heritable relationship and variability of oil content and agronomic characters in the $\mathrm{F}_{2}$ generation of soybean crosses. Agron. J., 44: 202-209.

Yousef, E., Carmi, A., Nikbachat, M., Zenou, A., Umiel, N. and Miron, J. 2009. Characteristics of tall versus short-type varieties of forage sorghum grown under two irrigation levels, for summer and subsequent fall harvests, and digestibility by sheep of their silages. Anim. Feed. Sci. Tech., 152: 1-11.

\section{How to cite this article:}

Balasamy Jayaraman Karthikeyan, Chakrapani Babu and John Joel Amalraj. 2017. Nutritive Value and Fodder Potential of Different Sorghum (Sorghum bicolor L. Moench) Cultivars. Int.J.Curr.Microbiol.App.Sci. 6(8): 898-911. doi: https://doi.org/10.20546/ijcmas.2017.608.112 
Appendix.1 Trait descriptor list

\begin{tabular}{|c|c|c|c|c|}
\hline $\begin{array}{c}\text { S. } \\
\text { No. }\end{array}$ & Character & $\begin{array}{l}\text { Trait } \\
\text { code }\end{array}$ & Method & $\begin{array}{c}\text { Unit/ } \\
\text { Measurement }\end{array}$ \\
\hline 1. & Plant height & PLH & $\begin{array}{l}\text { Main stalk - measured from ground level to tip of } \\
\text { the panicle }\end{array}$ & $\mathrm{cm}$ \\
\hline 2. & Stem girth & STG & Diameter or width of the $4^{\text {th }}$ internode from top & $\mathrm{cm}$ \\
\hline 3. & $\begin{array}{l}\text { Number of tillers per } \\
\text { plant }\end{array}$ & NOT & Total number of tillers in each plant sample & - \\
\hline 4. & $\begin{array}{l}\text { Number of leaves per } \\
\text { plant }\end{array}$ & NOL & Total number of leaves in each plant sample & - \\
\hline 5. & Leaf breadth & LEB & $\begin{array}{l}\text { Width of the } 3^{\text {rd }} \text { leaf blade from top at its widest } \\
\text { point }\end{array}$ & $\mathrm{cm}$ \\
\hline 6. & Leaf length & LEL & Length of the $3^{\text {rd }}$ leaf from top, from base to tip & $\mathrm{cm}$ \\
\hline 7. & Leaf-stem ratio & LSR & Ratio of leaf weight to stem weight & - \\
\hline 8. & $\begin{array}{l}\text { Green fodder yield per } \\
\text { plant }\end{array}$ & GFY & Average weight of the plant & $\mathrm{g}$ \\
\hline 9. & $\begin{array}{l}\text { Dry fodder yield per } \\
\text { plant }\end{array}$ & DFY & $\begin{array}{l}\text { Average weight of the plant under moisture free } \\
\text { basis }\end{array}$ & $\mathrm{g}$ \\
\hline 10. & Crude fibre content & $\mathrm{CFC}$ & AOAC, 1990 & $\%$ \\
\hline 11. & Crude protein content & $\mathrm{CPC}$ & AOAC, 1995 & $\%$ \\
\hline 12. & Ether extract & EET & AOAC, 1980 & $\%$ \\
\hline 13. & Crude ash content & CAC & Ash of animal feed, 942.05 (AOAC, 1990) & $\%$ \\
\hline 14. & Acid detergent fibre & $\mathrm{ADF}$ & Van Soest et al., 1991 & $\%$ \\
\hline 15. & Neutral detergent fibre & NDF & Van Soest and Goering, 1990 and Mertens, 1992 & $\%$ \\
\hline 16. & $\begin{array}{l}\text { Non-fibre } \\
\text { carbohydrates }\end{array}$ & NFC & Weblink - Nutrition and feed terms & $\%$ \\
\hline 17. & Nitrogen free extract & NFE & Weblink - Nutrition and feed terms & $\%$ \\
\hline 18. & $\begin{array}{l}\text { Total digestible } \\
\text { nutrients }\end{array}$ & TDN & John Moran, 2005 & $\%$ \\
\hline 19. & Digestible dry matter & DDM & Moore and Undersander, 2002b & $\%$ \\
\hline 20. & Dry matter intake & DMI & Moore and Undersander, 2002b & $\%$ \\
\hline 21 & $\begin{array}{l}\text { Relative forage } \\
\text { quality }\end{array}$ & RFQ & Moore and Undersander, 2002a,b & - \\
\hline 22. & Metabolisable energy & MER & John Moran, 2005 & $\begin{array}{l}\mathrm{MJ} \mathrm{ME} / \mathrm{Kg} \\
\mathrm{DM}\end{array}$ \\
\hline
\end{tabular}

Appendix.2 Genotypic correlation coefficient for the various traits under study

\begin{tabular}{|c|c|c|c|c|c|c|c|c|c|c|c|c|c|c|c|c|c|c|c|c|c|c|}
\hline 1 & $\begin{array}{l}\mathbf{P} \\
\mathbf{L} \\
\mathbf{H}\end{array}$ & $\begin{array}{l}\text { S } \\
\text { T } \\
\text { G }\end{array}$ & $\begin{array}{l}\mathbf{N} \\
\mathbf{O} \\
\mathbf{T}\end{array}$ & $\begin{array}{l}\mathbf{N} \\
\mathbf{O} \\
\mathbf{L}\end{array}$ & $\begin{array}{l}\mathbf{L} \\
\mathbf{E} \\
\mathbf{B}\end{array}$ & $\begin{array}{l}\mathbf{L} \\
\mathbf{E} \\
\mathbf{L}\end{array}$ & $\begin{array}{l}\mathbf{L} \\
\mathbf{S} \\
\mathbf{R}\end{array}$ & $\begin{array}{l}\mathbf{G} \\
\mathbf{F} \\
\mathbf{Y}\end{array}$ & $\begin{array}{l}\text { D } \\
\text { F } \\
\mathbf{Y}\end{array}$ & $\begin{array}{l}\mathbf{C} \\
\mathbf{F} \\
\mathbf{C}\end{array}$ & $\begin{array}{c}\text { CP } \\
\text { C }\end{array}$ & $\begin{array}{l}\mathbf{E} \\
\mathbf{E} \\
\mathbf{T}\end{array}$ & $\begin{array}{l}\text { C } \\
\text { A } \\
\text { C }\end{array}$ & $\begin{array}{c}\text { A } \\
\text { DF }\end{array}$ & $\begin{array}{l}\mathbf{N} \\
\mathbf{D} \\
\mathbf{F}\end{array}$ & $\begin{array}{c}\mathbf{N F} \\
\mathbf{C}\end{array}$ & $\begin{array}{c}\text { NF } \\
\mathbf{E}\end{array}$ & $\begin{array}{l}\mathbf{T} \\
\mathbf{D} \\
\mathbf{N}\end{array}$ & $\begin{array}{l}\text { D } \\
\mathbf{D} \\
\mathbf{M}\end{array}$ & $\begin{array}{c}\text { D } \\
\text { MI }\end{array}$ & $\begin{array}{c}\mathbf{R F} \\
\mathbf{Q}\end{array}$ & $\begin{array}{l}\mathbf{M} \\
\mathbf{E} \\
\mathbf{R}\end{array}$ \\
\hline $\begin{array}{l}\mathbf{P} \\
\mathbf{L} \\
\mathbf{H}\end{array}$ & $\begin{array}{l}1.0 \\
00\end{array}$ & $\begin{array}{c}- \\
0.3 \\
03\end{array}$ & $\begin{array}{c}0.7 \\
59 * \\
*\end{array}$ & $\begin{array}{l}0.4 \\
34 \\
*\end{array}$ & $\begin{array}{c}- \\
0.2 \\
10\end{array}$ & $\begin{array}{l}0.4 \\
67 \\
*\end{array}$ & $\begin{array}{c}- \\
0.4 \\
32^{*}\end{array}$ & $\begin{array}{c}0.8 \\
36 * \\
*\end{array}$ & $\begin{array}{c}0.8 \\
21^{*} \\
*\end{array}$ & $\begin{array}{l}0.4 \\
41 \\
*\end{array}$ & $\begin{array}{c}- \\
0.35 \\
7 *\end{array}$ & $\begin{array}{l}- \\
0.2 \\
20\end{array}$ & $\begin{array}{c}- \\
0.23 \\
5\end{array}$ & $\begin{array}{c}0.40 \\
8^{*}\end{array}$ & $\begin{array}{c}0.4 \\
29 *\end{array}$ & $\begin{array}{c}- \\
0.17 \\
2\end{array}$ & $\begin{array}{c}0.04 \\
4\end{array}$ & $\begin{array}{c}- \\
0.07 \\
8\end{array}$ & $\begin{array}{c}- \\
0.40 \\
8^{*}\end{array}$ & $\begin{array}{c}- \\
0.43 \\
5^{*}\end{array}$ & $\begin{array}{c}- \\
0.37 \\
4 *\end{array}$ & $\begin{array}{c}- \\
0.07 \\
9\end{array}$ \\
\hline $\begin{array}{l}\mathbf{S} \\
\mathbf{T} \\
\mathbf{G}\end{array}$ & & $\begin{array}{l}1.0 \\
00\end{array}$ & $\begin{array}{c}- \\
0.2 \\
62 \\
\end{array}$ & $\begin{array}{c}- \\
0.1 \\
09\end{array}$ & $\begin{array}{l}0.3 \\
13\end{array}$ & $\begin{array}{l}0.1 \\
01\end{array}$ & $\begin{array}{c}0.0 \\
19\end{array}$ & $\begin{array}{l}0.1 \\
82\end{array}$ & $\begin{array}{l}0.1 \\
79 \\
\end{array}$ & $\begin{array}{l}0.0 \\
57\end{array}$ & $\begin{array}{c}0.33 \\
4\end{array}$ & $\begin{array}{l}0.3 \\
89 *\end{array}$ & $\begin{array}{c}0.26 \\
5\end{array}$ & $\begin{array}{c}0.10 \\
1\end{array}$ & $\begin{array}{l}0.0 \\
05\end{array}$ & $\begin{array}{c}0.11 \\
0\end{array}$ & $\begin{array}{c}0.11 \\
9\end{array}$ & $\begin{array}{c}0.34 \\
8^{*}\end{array}$ & $\begin{array}{c}0.10 \\
2\end{array}$ & $\begin{array}{c}- \\
0.02 \\
9\end{array}$ & $\begin{array}{c}0.15 \\
1\end{array}$ & $\begin{array}{c}0.34 \\
7^{*}\end{array}$ \\
\hline $\begin{array}{l}\mathbf{N} \\
\mathbf{O} \\
\mathbf{T}\end{array}$ & & & $\begin{array}{l}1.0 \\
00\end{array}$ & $\begin{array}{l}0.2 \\
14\end{array}$ & $\begin{array}{c}- \\
0.2 \\
18\end{array}$ & $\begin{array}{l}0.3 \\
31\end{array}$ & $\begin{array}{l}- \\
0.3 \\
27\end{array}$ & $\begin{array}{c}0.8 \\
08^{*} \\
*\end{array}$ & $\begin{array}{c}0.8 \\
32^{*} \\
*\end{array}$ & $\begin{array}{c}0.4 \\
18 \\
*\end{array}$ & $\begin{array}{c}- \\
0.27 \\
5\end{array}$ & $\begin{array}{l}- \\
0.1 \\
45\end{array}$ & $\begin{array}{c}- \\
0.05 \\
7\end{array}$ & $\begin{array}{c}0.30 \\
7\end{array}$ & $\begin{array}{l}0.2 \\
44\end{array}$ & $\begin{array}{c}- \\
0.09 \\
5\end{array}$ & $\begin{array}{c}0.08 \\
7\end{array}$ & $\begin{array}{c}- \\
0.19 \\
1\end{array}$ & $\begin{array}{c}- \\
0.30 \\
7\end{array}$ & $\begin{array}{c}- \\
0.26 \\
5\end{array}$ & $\begin{array}{c}- \\
0.27 \\
9\end{array}$ & $\begin{array}{c}- \\
0.19 \\
3\end{array}$ \\
\hline
\end{tabular}




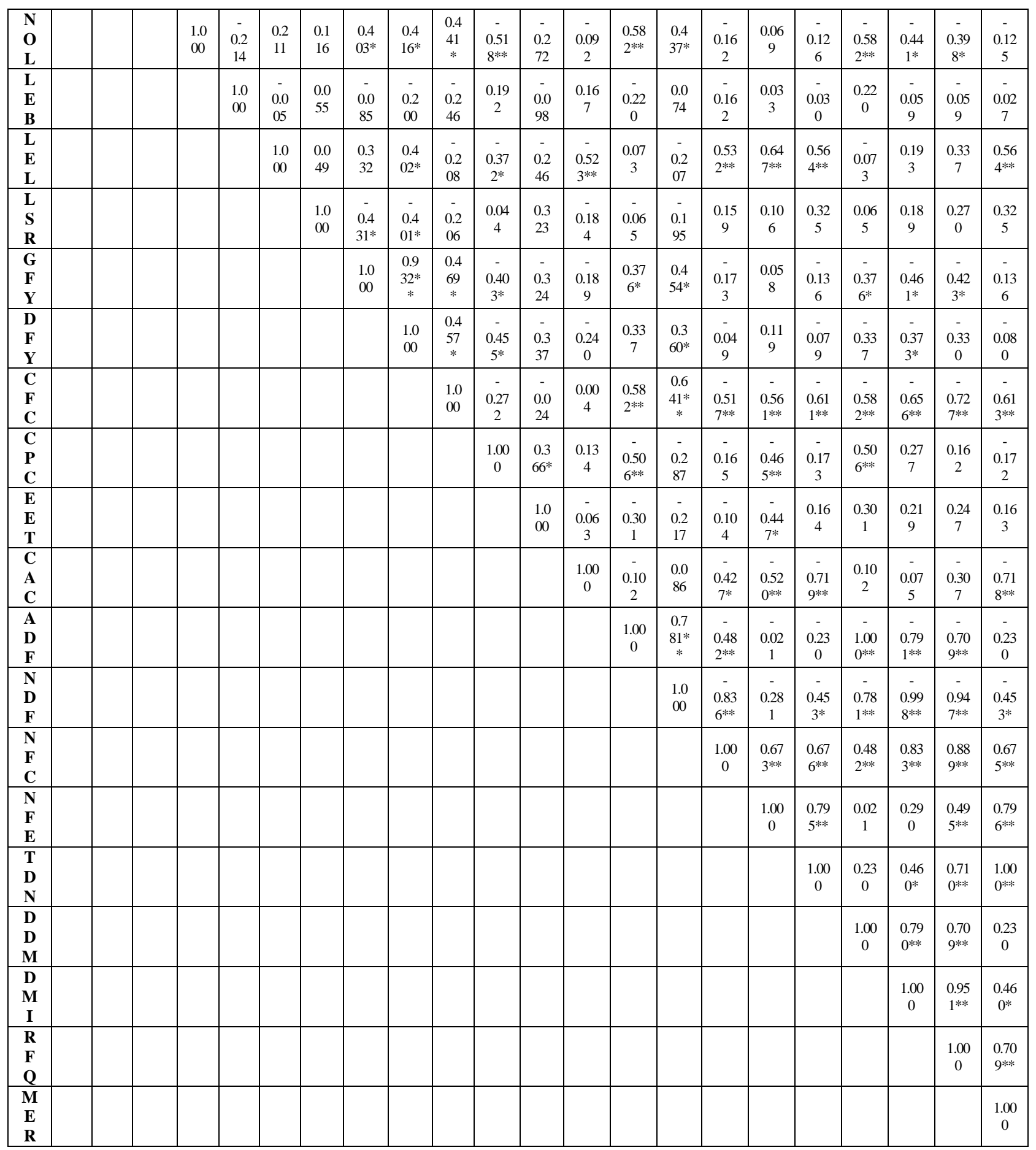

